\title{
論説
}

UDC 621.002. 3: $669.14 / .15$

\section{最近の新鋼種 展呈}

荒 木透*

\section{Trend of New steels in Recent Japan}

\section{Tôru Araki}

\section{Synopsis}

The author classified the latest new steels, from the view point of usage, into 3 groups, high tensile steels, high strength and ultra high strength steels and steels for special uses, and described details and principles of developing new steels and also their future tendency.

As to high tensile steel, the outline of Japanese standards, recent trend towards strengthening of steels, the future of antiweathering steel and seawater resisting steel, and super strength structural steel, PZ steel and $\mathrm{MB}$ steel which were recently developed are described.

In the article of high strength steel, the author stated about significance of steels standardized in JIS.

And classifying ultra high strength steel from the view point of alloy content the author firstly described the transition from 4340 steel to HP 9-4 steel with the low alloy series, and as to the medium alloy series the application of hot work die steel and matrix steel etc. for high strength use was also touched on.

As for the high alloy ultra high strength steel which is primary represened by maraging steel, the author described about strengthening mecha$\mathrm{nism}$ and fracture toughness, and further explained about microdeplex and TRIP steel as examples of a new direction of technical development.

Taking up stainless and heat-resisting steel as steels for special use, the author outlined the influence of alloying elements and microstructure to strengthening, corrosion protection, and oxidation resistance and about the direction of further development in the future.

The author also explained briefly the new trend of free-machining steel.

* 東京大学教授, 工博 


\section{1. 粕 晋}

まず最近の鉄鋼材料の進歩のあとを振り返ってみよ 5。新しい成分，組織を持った新鋼種か開発研究の結 果つぎつぎに出現し，これによって鋼材料としての新 しい優れた性能が漸次達成されて需要家の要望を充た しつつあることがみられる。また一面，量産製造方式 の革新とともに相対的なコストダウンと品資の向上， 新しい用途の払大が行なわれて, 従来の高䄲鋼の一般 化普及化が行なわれつつあり，この面です性能と用途 に関連した新しい領域の開発が進んでいる。このよ5 に自由世界第 2 位の生産量を誇る材料としての鉄銅の 羅進は, 建設, 機械, 車輛, 造船, 化学工業などわが 国工業の発展を基硽から支える役割りを果していると い克よ5。さらにまた宇宙航空, 原子力, 海洋開発な ど新しい工業に要求される材料の面です今後に向って 多くの期待を担っていると思われる。

これら新しい鋼の実状と傾向を展望するに当り，ま ずその用途と治金学的な分類によって整理して考えて みると，大別して，强度的用途の各種合金鋼一（主と して構造用，機栈部品用，工具用など）と，特殊性能 用途の高合金鎆一（不銹銅，耐熱鋼，高速度鋼，非磁 性䤡など)に区別することができよ5。すちろん，こ れらのものの中間的領域のものも存在するが，以下こ れらの用途によって要求される性能の5ち, 強度的な るのを主として最近の新鋼種の動向を概観することと する。

\section{2. 強度を高めた鋼種}

\section{1 高張力鎆}

構造用普通鋼材二㜞銅の 6.つ引張強さ $\sigma_{\mathrm{B}} \sim 41 \mathrm{~kg} /$ $\mathrm{mm}^{2}$, 降伏強さ $\sigma \mathrm{y} \sim 24 \mathrm{~kg} / \mathrm{mm}^{2}$ 程度の力をさらに向 上させた「高張力鋼」としては，低価格で経済性の高 い非調質型「フェライト・バーライト鍮」と，高強度

Yield strength-tensile strength $\left(\mathrm{kg} / \mathrm{nmm}^{\prime}\right)$

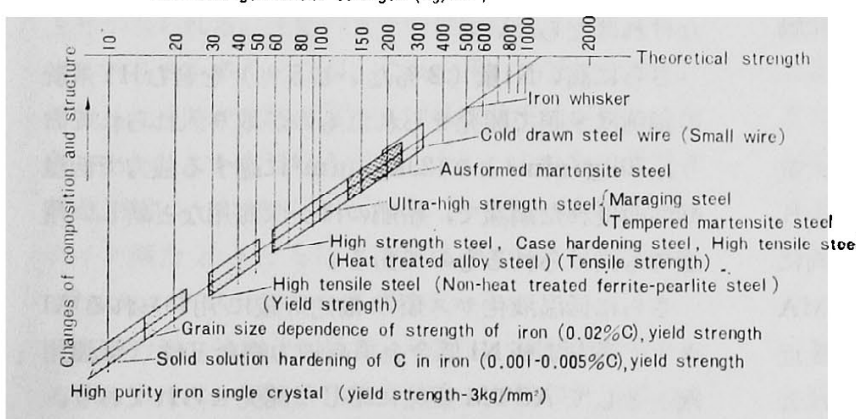

Fig. 1. Strength spectrum of steel.
の調筫型の「焼もどしマルテンサイト鎆!に大別して 考えることができる。

\subsection{1 非阙蜸高張力的}

非調質型としては，非鎮静銅をす含み低炭素鎆に $\mathrm{Nb} ， \mathrm{~V}$ 等を $0.05 \%$ 程度添加処理した細粒，析出硬化型 の高張力鋼があって，その改良普及化にはみるべき例 が多い。要求される性能の主体は，「強度」と適当な 「勒性」(切欠鞄性, 世ん移特性)「溶接性」であって, 多くのこの種のものか汪延，処理，管理技術の改善と 関連して開発されてきてきいる。

溶接技術の進歩とともに溶接構造物（橋梁，船舶， 压力容器など）の発達は著しく，これに合わせて溶接 性と強度の優れた新しい鋼種が多く生み出された。こ れらのすのの内容を概説すると，

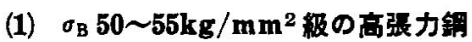

大約 $1.4 \% \mathrm{Mn}, \mathrm{C} \leq 0.2 \%$ 低マンガン低宸素のキ ルドないしセミキルド鋼が標準であるが，JIS-50YB 相当品には $\mathrm{Nb}, \mathrm{V}$ 等（その他場合によっては $\mathrm{Al}, \mathrm{N}$ な ど）を少量（0.5 0.1\%程度）配合して，压延状態で 降伏強さを $36 \mathrm{~kg} / \mathrm{mm}^{2}$ 以上に高めたものが開発され ている。これらは溶接性と経済性の優れた量産用構造

Yield strength $(\mathrm{kg} / \mathrm{mm}:)$

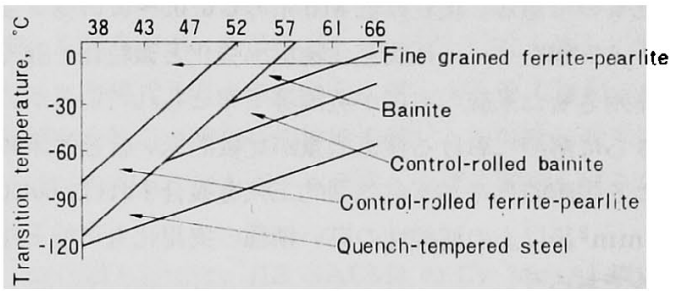

Fig. 2. Example of schematic explanation of mechanical properties (balance between strength and transition temperature of notch impact value) of low $C$ structural steel, fine grained or sub-hot worked (control-rolled)

压延鋼材として将来㜞鎆に代わって行くべき ものと考えられる。

強度の向上ととすにとくに高い切欠衝撃勒 性を確保するためには，フェライト結晶粒の 微細化が最も有利である。このためにはもち ろん Al キルド銅ないし積極的に $\mathrm{Al}, \mathrm{N}$ の添 加（IN 处理）鋼とすることが析出分散系の 微粒効果として著しく有奻であるし，また $\mathrm{Ti}, Z \mathbf{r}$ などの窒化物の効果の利用も強靶細粒 化に用いられる。さらにNb, Vなどの炭窒化 物 $\left[\mathrm{Nb} \mathrm{C}_{0.85} \mathrm{~N}_{0.1}, \mathrm{~V}(\mathrm{~N}, \mathrm{C})\right.$ などの形の 
もの了の析出強化系のものです熱間仕上区延の過程を 変態点直下に至る低温にもってくる亜熱間加工によっ て，微細結晶粒の勒性に富んだ組成とすることができ る。具体的な鋼としては製造者によって成分例か若干 異なると同時に，加工および熱的な管理技術に種々の 工夫をこらしたすのか開発，研究されつつある(Fig. 2)。

(2) $\sigma_{\mathrm{B}} 60 \mathrm{~kg} / \mathrm{mm}^{2}$ 級の高張力鋼

压延のままあるいは焼ならしによって降状強さ46〜 $50 \mathrm{~kg} / \mathrm{mm}^{2}$, 引镸強さ $60 \mathrm{~kg} / \mathrm{mm}^{2}$ 級のものは実用銅と して登場しつつある。析出強化之細粒強鞄化を組合せ た上述の鋼種に Si，Mnを増強し，あるいはさらにま た微量の $\mathrm{Ni}, \mathrm{Cr}, \mathrm{Cu}$ その他を襀合した形のるのもあ る。これらは $\mathrm{Ni}, \mathrm{Cr}, \mathrm{Mo}, \mathrm{Cu}, \mathrm{V}$ などを少量複合添 加し調質（焼入れ焼もどし）によって强勒化を計る形 で一足先に開発されていた $60 \mathrm{~kg}$ 䄲以上の高張力鋼上 りる経済性において優れている。

以上の各種のものの溶接性をさらに高めるために C\%を極端に下げたいわゆる無バーライト構造用鎆 (pearlite-free or-reduced steel) と称せられるす のも新しく研究開発されつつある。このよ5な鋼の生 産は現在の純酸素転炬法によって経済的に可能となっ たすのである。現在は低 $\mathrm{Mn}$ 系のC 0.05 0.07\%フェ ライト銅をべースに宸空化物析出强化と䵊粒化を強く 作用させた系統のものが英国等で報ぜられているが， さらに溶接における炭素当量が比較的低い合金元素に よる固溶強化や加工熱処理的工夫を複合すれば， $60 \mathrm{~kg}$ $/ \mathrm{mm}^{2}$ 級以上の溶接性の高い鋼種の実用化す可能とな るであろ5。

鉄筋コンクリート用棒銈 JIS SD35，SD50（降伏 強さ $35 \mathrm{~kg} / \mathrm{mm}^{2}$ あるいは にる溶接構造用銷と類似のアイディアが投入されう る。単にCを高め $\mathrm{Mn}, \mathrm{Si}$ の固溶強化とパーライト増 加を主体として高降代点とすることが行なわれていた が，さらに工法の変化により溶接，㱛接などの性質を よくする必要も生じつつあるから，Cを低め炭金化物 の微細析出と細粒化が利用されるようになった。

\section{（3）耐候性高張力銅，耐海水銅等}

「耐倔性銅」は銿材の大きな弱点の一つである大気 中での腐食减耗に対する耐入度を高めるエ夫から生れ たもので，将来の一般楧造用鋼材はすべてこの方向に 工夫されて行くことも考えられる。JISでは SMA $41 ， 50 ， 58$ の溶接構造用耐候性熱間压延銅材者最近 決定した。土木, 橋梁, 車輌方面での今後の伸びは著 しいものとみられる。この鋼種は Cuおよび Cr を主
要な耐候性の銹びを形成する成分として含有してお り，それぞれ Cu 0.2〜0.7\%，Cr 0.3〜1.2\%を規定 している。さら沉高張力耐候性鋼の SMA 50, ( 58) では Mo, Nb, Ni, Ti, V, Zrの5ち一種類以上を 源加することと定めている。これら添加元素は国内各 メーカーの開発研究の結果推奖されている特殊成分で

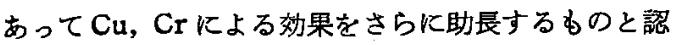
められている。

さらに一般用圧延鎆材の耐侯鋼は最初 U. S. Steel のCorten で開発されたよ 5 K，以上の成分の他 0.1 \%程度の $\mathrm{P} か \mathrm{Cu}$ と共存して耐候性に有效なことが知 られている。Pが含まれることから溶接性には適しな いか洏㬋性はさらに良好となるので，この種の鋼種す 建策, 車唡, 産業機械方面への需要を狙って各製鎆メ 一カーが新製品の性能を競っている現状である。

海水による腐食にさらされる用途には「耐海水鋼」 が開発されている。而侯性銅と似た $\mathrm{P}, \mathrm{Cu}, \mathrm{Cr}$ など の有効成分の他 $\mathrm{Al} ， \mathrm{Ni} ， \mathrm{Ti}$ な゙が腐食量を減少する 成分として報告され，実用銅としては降伏強さ36〜 40 $\mathrm{kg} / \mathrm{mm}^{2}$ 粐の高張力のあのが 各種の「ハイル鋼材」 として世に出ている。

その他の環境としては，燃焼ガス中の $\mathrm{SO}_{2}\left(\mathrm{H}_{2} \mathrm{SO}\right.$ 4）などを考克て耐硫酸性を向上させる試みすなされ ている。この場合 $\mathrm{Cu}$ と Sの共存批よび $\mathrm{Sb}, \mathrm{As}, \mathrm{Sn}$, Seなどが有効であることが知られている。

\subsection{2 調筷高張力銅}

この種の複合低合金低炭素銅は $\mathrm{T}-1$ 銅以来すでに かなりの実䋶を経てきているが，価格的な面からみて 本質的により高い「強度」を目標とするすのである。 低温切欠靸性は高いか，搈接性においてはやや困難か： 増すのはやむを得ない。溶接用としてIN 処理, 析出 強化を併用して引張強さ $100 \mathrm{~kg} / \mathrm{mm}^{2}$ 釉のものす実用 銅として開発されている。この種の鋼の新しい発展の ためには溶接部材の低サイクル疲労強度や球形圧力容 器にみられるような応力腐食割れなどの難点を克服し なければならない。

さらに高いNi量（2\%ないし％）を含むHY系統 の鋼種は米国で開発せられたものか取り入れられてお $\eta, 70 \mathrm{~kg} / \mathrm{mm}^{2}$ より $120 \mathrm{~kg} / \mathrm{mm}^{2}$ に達する強力で低温 勒性の優れた鋼種で，船舶のほか深海用など新しい用 途にも向けられるすのである。

さらに低温液化ガス類の 輸送詝蔵に用いられる $\mathrm{Al}$ キルド系および Ni 低合金系高張力鋼などは「低温用 鋼」として ASTM 規格に準じて開発せられて扰り， その最高のものはー $196^{\circ} \mathrm{C}$ を保証する調質型 $9 \% \mathrm{Ni}$ 鎆 
である。さらに Niを Mnで圈き換えた型の C 0.07 $\%$, Mn 3.5\%, Ni 4\%, Mo 0.2\%, Cr 0.5\%の Al キルドなども発表せられている。

強度の低い $2 \%$ 台の Ni を含さものには「炡ならし」 による鋼すあるか，降伏强さ $40 \mathrm{~kg} / \mathrm{mm}^{2}$ を越えるす のには調犋型の Al キルド銓，Ni2.6〜 4\%の Ni-CrMo調質鋼などが知られている。

以上調質型の高張力鋼は，古くから强勒鎆に用いら れてきた技術的経験知識の上にその開発研究のべース

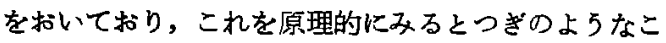
とがい古よ。

1) จルテンサイトを焼もどして得られるやや転位 密度が高く回復過程にある 紐粒のフェライトに微粒 のセメンタイトの分布した強勒な組織を利用する。 $\mathrm{AlN}$ ，微量のVは $\gamma$ 扰よび $\alpha$ 粒度を調整する役割り を果す。

2)したがって，良き性質を得るためには焼入性の よいことが有利であり，Mn， Ni， Cr， Mo， Cuなど の置换固溶型合金元素を有効に複合的に添加したり B 処理を行な5。

3) 溶接性の要求から有害不純成分の量を扰さえる とともに，炭素当量を下げる必要があり，基質は比較 的強度は低いが延性に䈏む低炭素マルテンサイトを焼 もどした組織となる。このことはまた $\mathrm{M}_{\mathrm{s}}$ 点か $400^{\circ} \mathrm{C}$ 程度に高いことを意味し，微覞組織の不均質性が多い ことが強度をさらに高めた㭙の問題点となろ5。

以上の上 5 な観点から,さらに強度を高めるには単 に従来の低合金系強勒錄, 肌狫釾の延長ではなく, 異な ったアイディフの採用が望ましい。米国その他では後 述の置換型合金元素の時効析出強化機構を利用した成 分のものか浂用高張力鋽として発表せられている。大 約 Ni 1.5\%，Cu 1\%，Mo 0.25\%位の低炭素鋁で圧 延状態でも 60 70 $\mathrm{kg} / \mathrm{mm}^{2}$ 級の引張強度を得られる が，調質を行ない $600^{\circ} \mathrm{C}$ 辺の時効処理を行なえば $\mathrm{Ni}$ $\mathrm{Cu}$ 系の析出強化により $100 \mathrm{~kg} / \mathrm{mm}^{2}$ 付近までの強度 上昇か得られる。压延のままの供給材はフェライト， ベイナイトを多く含むが，これを用いて部材を加工， 溶接した後時效処理を行な光ば降伏強度比が著しく改 善せられ，しかも延性を損なわない。これらの着想の 構造用鎙は，すでに知られれた Fortiweld 型のへィ ナイト鋼などととすに米国では Super strength structural steel とも名ゔけている。

瓷張力鋼の強力化を目指した新しい鎆種の着目され る例としては， $\mathrm{Nb}$ 炭化物の焼もどし時の析出による 2 次强化機構か：Moの共存によって著しく増強される
現象を利用したPZ銅や，Ni を多く含しだ低炭素べイ ナイト鎆が比較的低い降伏强度比を有し，延性が高い ことを利用して溶接特性を高めたMB銅などが挙げら

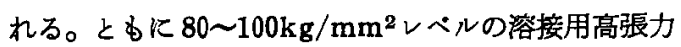
鋼の性能向上を目標にしており，前者は応力䋀食割机 に対する感受性の低下をる狙いとしている。

\section{2 强软鎡, 超强力鎆}

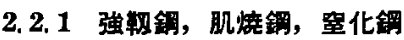

これらの鋼種はJISでは機械構造用合金鎆として用 途的に分類されているものである。これらのるのの成 分, 熱処理組織と強度鞄性の関連については前節の調 質型高張力鍴について述べたことが大体いい5る。古 くから発達した鋼種であって, 用途としては兵器, 自 動車, 機械部品などとして比較的シビフな强度的品質 が要求されてきている。したがってP，Sなどの不純 成分や偏析, 非金属介在物などに関する限定量の管理 が重要であり，この面と生産量の増大量産化に伴な5 製造技術面の合理化や品質管理の改良進步は多くのも のがなされているが，鋼種としてとくに新しいものは 少ない。

前述の Nb-Mo 采の哑もどし 2 次強化機構の応用 や, Fe-NiAl, Fe-NiCu, Fe-NiBe, Fe-NiSi, そ の他の系の多くの置换型合金元素の焼入れ時効強化機 構の利用などが，今後の新しい品質と性能を生み出す ために有望であると思われる。烧もどし2次強化と金 属間化合物系の時效析出段階の強化とを同時に発効さ せる時の相互作用を適当に利用した鋼の開発も試みら れている。

埕化鎆としては，JIS SACM1 の Cr-Mo-Al 鎆以 外飞(Ti，v放どの成分を窒化促進元素として有結 取り入れた䥔種か用いられている程度であろ5。例点 ば C 0.25\%, Ni 3.5\%, Cr 1.2\%, Mo 0.25\%, Ti (2.7\% Al 0.15\%のN-6 銅などが司速堂化銅として $600^{\circ} \mathrm{C}, 10 \mathrm{~h}$ の窒化処理を可能にしている。

肌焼銅としては，ガス浸炭支術の進歩とともに高温 浸炭による高能率化も問題になりこれに適した粗粒 化温度の高い粒度調整鋼か土夫される必要があるし， また合金成分としてはCーーホテンシャルの調整上 $\mathrm{Cr}$ \%の低いMoを多く含む系統の鎆が自動車用として着 目されるなど，性能と熱処理技術の関連で旧 JIS 鋼か ら新しい銅種への転換が後行なわれていくと思われ る。

\subsection{2 超强力铜}

新しい時代の鋼，超強力鋼とは大䄪 $140 \mathrm{~kg} / \mathrm{mm}^{2}$ 以 上の強度レペルの鎆を名つけけており，同時に必然的に 
super-duty であることを要求される。用途の主体は 強度/密度，ナなわち $\sigma / \rho$ を軽合金と競うような航空 機，口ヶット，深海用などである。一般の純度や清净 度を有する銅では，これ以上の搏度レベルにおいては 切欠強度比や疲学耐久限度比が強度とともに低下し， また環境の影㗽によっては遅れ破睘に対して敏感にな

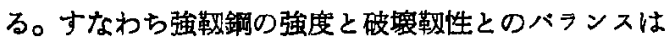
$140 \mathrm{~kg} / \mathrm{mm}^{2}$ 辺を境にした上部てはくずれてくるため K，強化鋼種としてまた別個の技術的要素が加わり， 勒性の評価法も異なったりのか泌要となる。真空溶解 や不純元素, 偏析などのシビアな限定が実際面の技術 として重要である。

便宜上，低合金鎆，中合金鋼，高合金銅と 3 大別し て考えると，それぞれが金属組織的には大体「低温焼 もどしマルテンサイト」「䙓炭化物による烤もどし2 次硬化組織」「置換型固溶元素を主とする過飽和立方 マルテンサイトの時効強化組織」に対応する。

以下わか国の実績が少ないので米国の例を主とし て述べ日本の開発状況についても触れる。

(1) 低合金超强力龬

Ni1. 7\%, Cr0.8\%, Mo0. 25\%の AISI 4340 (JIS SNCM 8）より改良発達したもので, 新しい着想とし ては，Si を高めて耐焼もどし性を向上させ $300^{\circ} \mathrm{C}$ 辺で 焼もどし脆性を生じさせないようにするととすに，併 せて固溶強化し $200 \mathrm{~kg} / \mathrm{mm}^{2}$ の引張强度を実用化した 300Mや，さらにC\%を下げて靬性を附加したHy-Tuf などの鋼か溉に多くの実績を経ている。

$\mathrm{Ni}$ を Co で置き換えた形の 4137 Co 鋼 (Co $1 \%$, Cr 1.1\%，Mo 0.25\%，C $\div 0.37 \% ）$ は薄板のロケッ トチャンバ材として破㐭䩓性值が優れているとされて 焼入れ組織の初析フェライト部やべイナイティクフェ ライトの混在による不均質性が少ないためとされてい るが，このよ5な低合金鐥を充分な冷却能で焼入れる 時の Co の金属組織学的役割りについてはなお研究す べきもがある。

$9 \mathrm{Ni}-4$ Co鋼（HP 9-4 -45など）は，母啠はNi， Co を多く固溶した含炭素マルテンサイトを焼もどし たもので，固体ロケットのキャンバ材として $180 \mathrm{~kg} /$ $\mathrm{mm}^{2}$ 級の强度レベルの薄板の破㙘䩓性值が優九てい るため, 先用上有用な鋼種とされている。低温用鎙に みられたよらに，かなりの\%の Ni は鞄性附与の効果 が大きい。これC。との組合せはマルテンサイト固 溶体の性質が，近似的K disorder K近い状熊の低合 金のものとは少し異なっているものと考光られる。

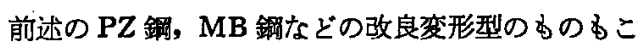

の種の鋼の下限の強度に用いれば，溶接性を発揮でき る特長を有するのでわが国のロケット用材料として 開発，㮩討がなされている。

低合金系超强力鎆の将来への可能性としては，さら に熱処理と塑性加工，すしくは綝返し急速熱变化など の組合せにより超微細粒の下部構造を得ることによっ て，強度の向上と䩓性を確保することが研究されてい る。

\section{（2）中合金敖强力销}

熱間ダイス鋼の一種である H11(JIS SKD6), H13 （JIS SKD61）などの改良型の鋼種が基をなしてお ク，Mo, $\mathrm{V}$ の複炭化物析出による 2 次強化を利用し たもので，耐熱性が高い点で低合金鑰をしのぎ，超音 速機体などの材料にも用いられる。機構的にはMo 1 \%を含む D6A など低合金鍋す同じ範围に入る。

さらに高䄲なるのとしてはMA鋼として知られる高

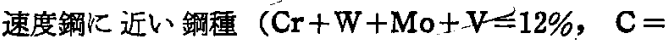
$0.55 \%$ ）が焼入れ焼もどし状態での引張強さ $240 \mathrm{~kg} /$ $\mathrm{mm}^{2}$ という含炭素マルテンサイトとしては極的て高

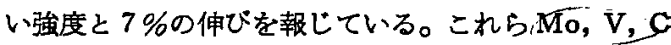
を含む超強力銅はオースフォーミングによって50〜70 $\mathrm{kg} / \mathrm{mm}^{2}$ の強度上昇を実現することができ，しかす 延性，勒性を損なわないことは特筆すべきことである。 これらの現象の内容にはつぎの機構が考劣られる。準 安定オーステナイトの加工時に格子久陷が多数道入さ れるがこれらと Mo，Vなどの特殊カーバイドの核 発生との間の相互作用が多く, その後の冷却変態に上 って生成するマルテンサイトの下部構造に受け継がれ て，㪣小セル組織を形成して強度と勒性を高めるるの とする考方方ある。

オーステナィトの加工と変態，さらに昰み時効を組 合せた加工熱処理により，現在鉄銅材料としてバルク の状態で最も強度と鞄性の高い鋼種は前記MA銅によ って達成せられ， $340 \mathrm{~kg} / \mathrm{mm}^{2}$ の引張強さとかなりの 延性，鞄性を有することが報告されている。

低合金系でこの鋼種に近い強化機構を有しているも のKD6AC (C0.47\%, Cr 1\%, Mo 1\%, V0.15\%) などのあのがあり，加工熱処理による強化や遅れ破燷 の点で優れていることが報告されている。

\section{(3) 高合金系超强力鈝}

この鋼種は歴史的には，ステンレス鋼の変身で強度 特性を生かした 17-4 PH など 初期の PH ステンレス 鋼の強度上界への努力から，18〜25Ni マルェージ鋼 の誕生に結びついて画期的な飛踓へ々進んだ。現状で はマルエージ銅扰よびマルェージ型ステンレス鋼に各 
Table 1. Examples of marage steel and marage stainless steel

\begin{tabular}{|c|c|c|c|c|c|c|c|c|c|c|c|c|c|c|c|}
\hline \multicolumn{3}{|c|}{ Steel } & $\mathrm{Ni}$ & Co & $\mathrm{Cr}$ & Mo & $\mathrm{Ti}$ & Nb & Al & C & $\mathrm{Cu}$ & $\begin{array}{c}\sigma 0.2 \\
\mathrm{~kg} / \mathrm{mm}^{2}\end{array}$ & $\begin{array}{c}\sigma \mathrm{B} \\
\mathrm{kg} / \mathrm{mm}^{2}\end{array}$ & $\delta \%$ & $\varphi \%$ \\
\hline 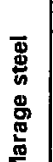 & 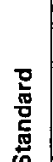 & $\begin{array}{l}18 \mathrm{Ni} \text { marage } \\
20 \mathrm{Ni} \text { marage } \\
25 \mathrm{Ni} \text { marage }\end{array}$ & $\begin{array}{l}18 \\
20 \\
25\end{array}$ & $\begin{array}{l}8 \\
- \\
-\end{array}$ & $\begin{array}{l}- \\
- \\
-\end{array}$ & $\begin{array}{l}5 \\
- \\
-\end{array}$ & $\begin{array}{l}0.5 \\
1.5 \\
1.5\end{array}$ & $\begin{array}{l}- \\
0.5 \\
0.5\end{array}$ & $\begin{array}{l}0.1 \\
0.25 \\
0.25\end{array}$ & $\begin{array}{l}\leqq 0.03 \\
\leqq 0.03 \\
\leqq 0.03\end{array}$ & & $\begin{array}{l}-170 \\
-170 \\
-170\end{array}$ & $\begin{array}{l}180 \\
180 \\
180\end{array}$ & $\begin{array}{l}11 \\
11 \\
11\end{array}$ & $\begin{array}{r}\sim 50 \\
50 \\
50\end{array}$ \\
\hline & & 15 Ni marage & 15 & 9 & - & 5 & 0.7 & & & $\leqq 0.03$ & & & -200 & & 50 \\
\hline 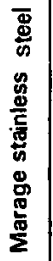 & $\begin{array}{l}\bar{\Phi} \\
\Phi \\
\frac{\Phi}{2} \\
\frac{T}{\alpha}\end{array}$ & $\begin{array}{l}\text { MA-164 } \\
\text { FV520 } \\
\text { AM367 } \\
14.8 \text { Mo } \\
\text { (Experimental) }\end{array}$ & \begin{tabular}{c|}
4 \\
5.5 \\
3.5 \\
8.5 \\
8
\end{tabular} & $\begin{array}{c}12 \\
- \\
15.5 \\
- \\
-\end{array}$ & $\begin{array}{l}12 \\
16 \\
14 \\
15 \\
14\end{array}$ & $\begin{array}{c}5 \\
2 \\
2 \\
2.2 \\
-\end{array}$ & $\begin{array}{c}- \\
0.3 \\
0.5 \\
- \\
0.5\end{array}$ & $\begin{array}{c}- \\
0.7\end{array}$ & $\begin{array}{l}1.2 \\
\mathrm{Be} \\
0.15\end{array}$ & $\begin{array}{c}\leqq 0.03 \\
0.07 \\
0.03 \\
<0.035 \\
\end{array}$ & $\begin{array}{l}3 \\
2\end{array}$ & $\begin{array}{l}129 \\
172 \\
154 \\
170\end{array}$ & $\begin{array}{r}-170 \\
146 \\
179 \\
165 \\
180\end{array}$ & $\begin{array}{l}19 \\
14\end{array}$ & 52 \\
\hline
\end{tabular}

Table 2. Initial precipitation from super saturated B.C.C. iron

\begin{tabular}{|c|c|c|c|c|c|c|}
\hline $\begin{array}{l}\text { Alloving } \\
\text { olsment }\end{array}$ & Precipitatos & $\begin{array}{l}\text { Stote of } \\
\text { preclpitation }\end{array}$ & $\begin{array}{l}\text { Hobit } \\
\text { plane }\end{array}$ & $\begin{array}{l}\text { Aatio of } \\
\text { atomic diametor } \\
\left(r_{2} / r_{f, u}\right)\end{array}$ & Noto & $\begin{array}{l}\text { Presipitation } \\
\text { on dinlocation or } \\
\text { grain toundary }\end{array}$ \\
\hline Au & Au-zont & Plate & 100 & 9.14 & & - \\
\hline cu & Cu-rich zone (bs) & Sphere & - & 1.00 & $\begin{array}{l}\text { (Rod-llike st } 7000^{\circ} \mathrm{C} \text {. } \\
\text {-.prose) }\end{array}$ & - \\
\hline Bo & Be-rich (bect) & Plate & 100 & 0.88 & $\begin{array}{l}82 \text { ordered lattice } \\
\text { (cohorent) }\end{array}$ & $\begin{array}{l}\text { On dielocation. } \\
\text { On groin boundary }\end{array}$ \\
\hline , & Be, Fe (Loves) & - & 111 & -. & Afging at high temp.) & - \\
\hline Mo & Mo-rien zone & . & 100 & 1,11 & $\rightarrow \eta^{\prime}(b \infty c)$ & - \\
\hline. & $\mathrm{Mo}_{1} \mathrm{Fa}_{1}(\mathrm{\mu l})$ & . & 110 & - & - & On dislocstion \\
\hline$w$ & W-rich zone & - & 100 & 1,12 & $\rightarrow \eta^{\prime}(b c c)$ & - \\
\hline - & $W, F=(w)$ & . & 110 & - & - & On dislocation \\
\hline * & WFe; (Leves) & - & $?$ & - & (Aging ot high temp.) & - \\
\hline Nb & NbFe, (Laveas) & . & 110 & $\$ .17$ & - & On dislocation \\
\hline $\mathrm{Ti}_{\mathrm{i}}$ & TiFe, ILavest & . & 110 & 1.15 & - & \\
\hline $\mathbf{p}$ & $\mathrm{Fo}, \mathrm{P}$ & - & 100 & - & $F \theta, P \rightarrow F \theta, P$ & $\begin{array}{l}\text { On dielocution - } \\
\text { in matrix }\end{array}$ \\
\hline
\end{tabular}

Precipitation on dislocation or grain boundary.

\begin{tabular}{|c|c|c|c|c|c|}
\hline $\begin{array}{l}\text { Alloying } \\
\text { olemort }\end{array}$ & Prosipitalos & $\begin{array}{c}\text { State of } \\
\text { Precipitation }\end{array}$ & $\begin{array}{l}\text { Habir } \\
\text { plane }\end{array}$ & $\begin{array}{c}\text { Retio ot } \\
\text { atomic diemeter } \\
\text { it: } / \text { rit.l }\end{array}$ & Note \\
\hline No, Al & NiAl I $(B C E)$ & (Sphere?) & & -1.0 .1 .15 & B2 ordered latice (coherent) \\
\hline$N_{i}, T_{i}, A_{1}$ & $\mathrm{Ni}_{\mathrm{A}} \mathrm{AlT}$. & & & $-1.0,1.16,1.15$ & \\
\hline $\mathrm{Ni}, \mathrm{Ti}$ & $N i, T i(\gamma \quad n)$ & (Platelat) & 111 & 1.0 .1 .10 & $\left(00\right.$, orderod- $.0 O_{*}$, Dlate-like) \\
\hline $\mathrm{Ni}, \mathbf{S i}$ & (N), Fo $)_{1}$ si & & & -1.0 .0 .95 & Do, ordered $\rightarrow 1$ \\
\hline Ni. Bs & NiBen tbec| & & & -1.0 .0 .88 & B2 ordered tattice (cohorent) \\
\hline Ni. Nb & $\mathrm{Ni}_{2}, \mathrm{Nb}\left(\mathrm{O}_{\mathrm{r}} \mathrm{thr}\right\}$ (bel) & Plate & & -1.0 .1 .15 & - \\
\hline Ni. Cu & C-rich zone & Sphere & & $-1.0,1.00$ & $\cdots \&$ (Ice) \\
\hline$N_{1}, M n n_{n}$ & Ni-Mn-rieh $(b \infty)$ & Plate & & .1 .0 & \\
\hline Ni. Mo & Mo-rich zane & . & 110 & 1.0 .1 .11 & Zono plate $\rightarrow$ C14 plate - like ( Ni, Mo) \\
\hline
\end{tabular}

Table 3. Examples of intermetallic compounds precipitated from iron alloy.

\begin{tabular}{|c|c|c|c|}
\hline Name & 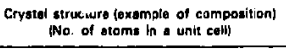 & \multicolumn{2}{|c|}{ Lattice porametar } \\
\hline$\theta(0)$ & $B$, (N) (A), Tii) / ordared bcc & $2.91-2.92$ & - \\
\hline$y$ & LI, (Ni, (AI, Ti) ) ordersed fcc & 3.6 & - \\
\hline$\eta$ & $\mathrm{DO}_{2 .}\left(\mathrm{Ni}, \mathrm{T}_{1}\right)$ hex & $5.11-5.12$ & B. $30-0.32$ \\
\hline$\eta$ & (Ni, Nb) orthorh & 5.10 & $4.25-4.50$ \\
\hline Lavos & C14 $\left(F_{0}, W\right)$ hax $(92$ sto. $)$ & $4.76-4.83$ & $7.80-77$ \\
\hline Loves & C1 $(F \theta, 2$,$) cub (24$ ato. $)$ & $6.8-7.1$ & - \\
\hline$\mu(\varepsilon)$ & $\mathrm{OB}, \mid \mathrm{Fo}$, Mos wigo & $4.78-4.79$ & $25.7-25.9$ \\
\hline$x$ & 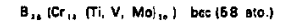 & $8.81-8.94$ & - \\
\hline e & $D B_{*}[$ focr] torrago $\mid 30$ oto. $)$ & $8.79-$ & $4.55-$ \\
\hline G & - $\quad(\mathrm{Ni}, \mathrm{Ti}, \mathbf{S i}, \mathbf{j}$ tec & $11.13-11.47$ & - \\
\hline ค & A, $_{0}\left(F_{0}, \mathrm{Cr}_{\mathrm{r}} \mathrm{Mo}_{0}\right)$ hex $(159$ sto. & $10.90-10.93$ & 19.34- \\
\hline
\end{tabular}

種のものか研究開発され，搏来の高強度鎆と して発展の途にある(Table 1)。

これらの鋼種に応用される直換型合金元素 としてはNi, Co, Mo, Cu, Be, Ti, Nb, $\mathrm{Al}, \mathrm{Si}$ ながCを含まない方方晶マルテンサ イトに過飽和に含まれた場合， $400 \sim 500^{\circ} \mathrm{C} の$

昇温特効によって母相の強度上昇を有效に起 こさせることが研究されてきている。現象と しては格子欠陷の多いbcc 固溶体結晶の中 で，固溶原子のクラスタるしくはゾーンのよ 5な初期の凝集，また短範囲，長範囲の規則 化のような微視的変化が昇温によって生起す る段階て著しい强化が観察され，さらに電子 顕微鏡に認められる金属間化合物や規則格子 相の析出が成長した段階で過時効となって 軟化に向 5 。この時逆㚆態によるオーステ ナイトの生成強度と鞓性に関連してくる (Table 2, 3)。

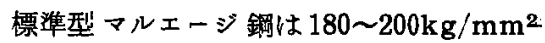
超強力レベルに批いて破壤鞠性 $\mathrm{K}_{\mathrm{I}}$ 值 (平面 歪みの臨界応力抎大保数）が他の鋽種に比へ て優れていることが評価されて，ロケットそ の他の超高信頼度を要求される部材に用いら れつつあるが，さらに Niを 12〜15\%に減じ たものや，Co量を特に高めた $240 \mathrm{~kg} / \mathrm{mm}^{2} レ$ ベルのあのなどあ試みられている。 $\mathrm{Cr}, \mathrm{Mn}$ をるって Niを置換した鎡種る多く研究され ている。Crを含むステンレス型のあのには。 
AM367 Gr14\%, Ni 3.5\%, Co 15.5\%, Mo $2 \%$ (Ti 0.5\%) や, か力国で開発されている MA164 (Cr 12 $\%, \mathrm{Ni} 4 \%$, Cu 3.2\%, Co12\%, Mo 5\%), ST 154 $\mathrm{PH}$ (Cr 15\%, Ni 4.5\%, Co 4.5\%, Mo 2.5\%,-ND 0.6\%) など Ni-Co-Mo 系の強化機構を骨子にしてい るすのか実用鉂として出ている。

高合金系統の強力鎆とこれにつつくく $\mathrm{PH}$ スンレス 鎆は，その時効，熱好理挙動々強度特性に与兄る影㗽 とい5点に打いて非鉄合金類と似た点があるが，母質 はC，Nなどの侵入型固溶原子の影響を 5 け基䂾的理 論的な裹付け研究によって開発を進めるということに おいては困難な点が多い。しかし高性能のるのを量産 的に製造するための技術的知識や熱処理，溶接，加工 などの銅材料に対する実際面の技術には多くの蓄積と 体系がでさているので，新しいアイディアによる変わ った性能の鋼が実用鍓として開発されるには，既に解 泆されている知識か沁用されて容易な面も多いと考元 られる。

一つの新しい方向として，フェライトーオーステナ イトあるいは時效マルテンサイトーオーステナイトの 二相を有する鎆の特殊な強度と塑性，勒性が現在唡討 されつつある。いわゆる microduplex と称する微細 な混合二相組織においては，昇温時特殊なミク口的塑 性が観察される条件がある。これが常温の性質にどう 結びつくかが課題である。

マルエージ鋼の或る種のむのでは，若干のミクロ的 に核発生した逆変態オーステナイトの存在か降伏强さ などの強度にあまり大きな影響を与えずに，マク口的 には延性を与える原因をなしているとも考えられてい る。

さらにォーステナイトを常温に持ち越した型の鎆 種, とくにMd 点が常温直上にある合金鋼オーステナ イトは，塑性変形によってマルテンサイト変熊が誘起 され，それによってさらに新しい塑性を生み出される ことが応用されて「TRIP (Transformafion induced plasticity) 鎙」が最近の話題を提供してい る。

Zackayによって報ぜられたものには，一例として C 0. 25\%，Ni 24\%，Mo 4\%などを基本とする含炭素 合金鋼がある。例点ば溶体化烍入れ状態では準安定才 ーステナイトであるが，常温の強加工によって多くの 部分がマルテンサイト化すると同時に，残留オーステ ナイトは極めて多くの格子久皕を導入されて高降伏点 となる。これを焼もどすことによってMo複炭化物の反 応析出が行なわれて母質の Mo，C量が若干失なわれ，

\section{〔宣気制鎆 第41巻 第 1 号}

残留の加工オーステナイトは不安定化してつぎの常温 望性変形によって再び変態を誘起する状態となる。

このよ 5 な鎙では $200 \mathrm{~kg} / \mathrm{mm}^{2}$ 䄲の降伏强さでしか も20\%台の伸びを観測するという箐異的な結果が壳ら れており，まことに画期的なるのと言えよう。

また太田氏によって研究されてきた Siteel と称す る $5 \% \mathrm{Si}$ K Cr， Ni，Vなどを主成分とする極低炭素 合金鋼オオーステナィトの塑性をSiの固溶強化と $\mathrm{Cr}$, $\mathrm{Ni}, \mathrm{Mo}, \mathrm{Si}$ などの時効析出強化現象などが組合され

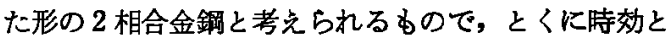
冷間加工の組合せによって高い降伏強さと高い延性 （靱性）のあるものの実験結果を得ているところは着 目すべきののと考えられる。

複合型の超強力鋼板については，グリフィスきれつ 発生と伝ばに対して特性の著しく異なった種類のるの を複合して不安定破㯰の防止に役立てようとするてィ ディフによるものがある。各種の試みが考えられるが， わが国においても多周の調質銅板を可塑性の大きい fcc の Ni などをボンドとして重ね合せて強圧延して 微細な層状組織を得る研究が注目される。

\section{3工具銅，朝受龬，ばね龬など}

主として高炭素系の低合金鋼類として代表的なすの には，軸受鋼および多くの合金工具鋼類，ばね鈴など がある。これらのすのに要求せられる性能は強度，硬 度に関連しているといってる特殊な転動疲労, 衝撃疲 労, 耐摩耗性など用途によって特長が異なる。金属組 織的な共通点の一つは, 球状化処理材の焼入れによっ て生じた残留炭化物分散型のマルテンサイトが利用さ れる点にある。

前述の中合金超強力銅としても一部の工具鎆か：利用 されるが，耐摩耗性の要求から，高硬度の合金褔炭化 物の粒子の分散した組織に重点がおかれたものが切削 やダイス関係の工具鋼である。母相のマルテンサイト の高い繰返しの匡縮，せん断応力に対する強度的応答 に重点が扐かれているものが軸受鍮とみられる。さら にばね鋼は母質の焼すどしマルテンサイトのばね特性 や繰返し応力に対する耐久限度が重点になり C量も比 較的低いものが用いられることが多いし，一部にはオ ーステンバなどベイナイト処理による組織の強靶性を 利用する場合やパテンティングー冷間加工による降状 点向上に重点を置くものるある。

高盜ダイス鎙やばね鎆の用途にはその要求性能の類 似性からマルエージ鐴やオースフォーム鎆の高強度上 靱性が新しい䤡種として利用されることが多い。また これらのものの中間的に, 単に $\mathrm{W}, \mathrm{Mo}, \mathrm{V}$ などの複 
炭化物反応 2 次硬化による 昇温強度の性能のみでな く, 新しい強化機構として Ni-Mo, Ni-Co-Mo など の時効（析出）強化を複合した成分の鑐種も種々のb のか開発されておりこれらの用途に用いられている。 しかし,この場合オースフォーム妈理は後者の機権に は活とんぞ寄与しないことが知られている。

軸受鋼としてはとくに清浄度との関連による溶解造 塊技術の進歩による品質向上が近年著しいが，さらに 長年の固定した成分 JIS SUJ $2 ， 3$ などから新しい より合理的な成分の低合金鋼への脱皮の動きがるられ る。

SUJ 2（C 1\%，Cr 1.5\%）を例にとればここれよ り転動疲学による破㥅現象に合理的に耐える母質を有 するる鋼としては，必要量以上の分散炭化物量をなくし， さらに強度上有効な合金成分や昇温時に焼もどし軟化 に耐える成分を加えることなどが考えられている。例 えばCを低めAlあるいはSiを1\%程度含有せしめて 耐熱軸受鋼としたるのや，Siさらには $\mathrm{Cr}, \mathrm{Mo}, \mathrm{V} な$ どを皘極的に添加した耐熱軸受鋼，さらに前節の MA

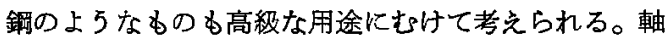
受に用いられる肌焼鋼についても同様のことがい光，

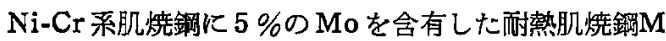
315 もその浸炭部の 熱処理組織は同様の主旨のものと 考えられる。

\section{3. 特殊性能の銅}

\section{1 ステンレス龬}

まず，標準の $18 \mathrm{Cr} ， 18-8$ などは量産方式の確立と とすに用途の拡大が計られつつある点に靚目すべきも のがめる。大型炬溶解，連続筹造と連続圧延方式によ りより一般的な而銹鎆板としての需要に応じ得るよう に向っている。さらに転炉による生産にも踏み切って おり, 価格と生産量の点でとくに建築, 家庭用, 車軦, 土木方面などにステンレスの普及鎙化が進んで行くで あろ5。

JIS 鋼としてはAISI とも対応した高䄲耐食鋼があ る程度整備されているが，さらに応力㓏食や特殊な化 学工業用の耐食性などの工夫を行なった鐉種も開発さ れつつある。

塩化物などを含む熱溶液における応力㢂食割れに関 して $\delta$ フイトーォーステナイトの 2 相組織が優れ ており，40\%あのフェライトを含を2相合金でマルテ ンサイトを形成しないるのの成分範囲として20-5 采 に少量の Si，Mo，Nを含む龬がわが国です開発され ていろがささらにMoを $3 \%$ 程度に高めたものは優れ
た特性を有することが外国で報ぜられている。 オーステナイト系統ではJIS 鋼より Mo 量の高い20 一25系に $5 \%$ Mo あるいはさらにCu を加克た系統の ものは，種々の特殊な酸類に対する耐食性を要求する ステンレスとして用いられる。これらはとくに炭素量 を0.02\%以下に抑える工夫がなされ ELC と称してい る。

タービン翼材などに用いる 12Cr系のス天ンレス鎆 飞 Ni $6 \%$ ，Co 7\%，Mo3\%を加文士析出硬化型、 ルテンサイト鋼はとくに内部摩擦一ダンピング特性の 高いことを目途としたステンレス鋼であるが，このよ うな特殊な性能が強度の高いところまで持続すること は高速回転器材として極めて望ましい。

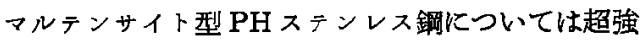
力銿の節でも述ベたが, $140 \mathrm{~kg} / \mathrm{mm}^{2}$ レベル以下の強 度で用いられるもので耐食性の優れたすのが多く開発 せられつつある。

3. 2 耐 熱 鎡

3.2.1 フェライト, マルテンサイト系

まず，低合金系には従来ボイラー材などとして発羍 してきた Cr-Mo 低炭素鋼類があるが， V, Cu， Ti， Bなどを少量添加した鋼種が英米で開発され $500^{\circ} \mathrm{C}$ 以 上へ性能の改善が試みられる。さらにガスタービン用 には，३\% Cr-Mo 鋼が用いられているが, Ti，Bの) （他 Nb を添加するなどして向上を計った鋼が開発され てर्ञ。

耐酸化性の優れた $9 \% \mathrm{Cr}$ 鎆では Mo，C当，Wに加 えてNb，V宸，窒化物の析出強化を計り， $600^{\circ} \mathrm{C}$ 辺で の強度を高めつつある。

さらに10〜 $12 \% \mathrm{Cr}$ 系の鋼については, Co の添加 が新しいマルテンサイト系の強力な耐熱鎉を生み出し つつあり $\mathrm{Co}, 5 \% \mathrm{Mo}$ ) などがあり，時效による置換固溶元素 の析出強化構をむ併世, 超強力鋼を $630^{\circ} \mathrm{C}$ 辺の耐熱 鎆として用いた形の鋼種とすみられる。またBの0.2

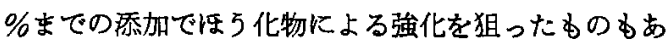
万。

$18 \% \mathrm{Cr}$ 系あるいはそれ以上の\% Cr の鋼種，耐酸 化, 耐硫黄に重点がおかれるすので, 結晶粒度のあ れやすいフェライト相に炭，窒化物析出系として Ti などを少量添加した銅種が利用される。さらに Al, $\mathrm{La}, \mathrm{Ce}, \mathrm{Y}$ などによって耐酸化性の向上を計ること む行なわれる。

CrK代わってAlを主合金とするフェライト鋼種す 新しい種類の 開発が着目されるすので， $7 \% \mathrm{Al}, 5$ 
$\% \mathrm{Cr}, 3 \% \mathrm{Zr}, 2 \% \mathrm{Nb}, 2 \% \mathrm{MO}$ 々 5 複合成分 のもの，あるいはさらに $\mathrm{Al}$ の高い鋼種などがある。

\section{2 .2 オーステナイト系}

18-8 上り25一20系に至る各種のオーステナイト耳 相に耐酸化性を高めるため $\mathrm{Si}, \mathrm{Al}, \mathrm{Be}, \mathrm{Y}$ などか利 用されるが，同時に時効析出現象も加わる。さらに Ti，Nb，Pなどを加克，あるいはまたMo，W，Cok 上る相の固溶体強化を狙った各種の新鍴種がらら る。Bは粒界強化とさらに積極的に压5化物析出によ る強化も利用されるものか研究されている。

MnはNi の代替元菜として研究され，これとNに 上る窒化物析出強化か利用される。并用鋼として多く 用いられる銅種はガソッン燃焼より来る酸化鉛に対す る耐食性が問題にされるが，Ni をMn に代替した系 統の鋼か優れている。

\section{3 快削 鋼}

快削性能は生産効率、重要な優れた被加工性能の一 つであるが，鋼の場合は研究の歴史が古くそれだけ知 識技術す多く皘み上げられ，冶金的研究を近来深くな されるよ5になった。

新鋼種としては,軟䤡べースの超快削鋼やダイス鋼， ステンレス鋼などの快削鋼化に多くの発表がみられ る。

すでに永く利用されてきている $\mathrm{S}$ ，Pb 系の各基本
鋼種に, 'Te, Se, Bit2どを如何に襢合添加して効果 を多くするが開発の眼目がある。 $\mathrm{N}$ ，Pなどの富化 については研究の詳細な点については興味か残されて いる。

とくに Teの添加銅には，独特の構成刃先への効果 によって工具寿命と仕上面に優れた性能を与える鋁卮 がある。超快削銅としてはSiの極めて低いリムド・ セミキルド系の鋼が常用され，とくに0.00\%台の低 Si のものも新たに見直されていると報ぜられている。

最近の技術開発の一つの話題は 乌a 脱酸に用いて シリケート采の非金属介在物を適当に調整した鋼であ る。

これらは超硬切削工具の攀耗に著しい改善がみられ る。150〜 250m/min の高速切削において，シリケー 卜を主体とする非金属介在物が工具接触面（すくい 面，逃忖面）に堆積して被覆する效果によるすので, 眖酸，造塊条件の調整， $\mathrm{Al}_{2} \mathrm{O}_{3}, \mathrm{CaO}$ などを適当に 含んたシシリヶートの分散を計ることが鎆の高速切削 （この場合含 $\mathrm{Ti}$ 系工具）における快削性能を高めた あのを得る。この場合, 硫化物の共存や介在物の絶対 量の効果など実用上への今後の課題はあるが，従来の 考克方と異なった新しい方向の快削鋼が生れて行く可 能性がある。 